\title{
The Correlation between Sleep Duration with Concentration Level on Elementary School Students in Denpasar
}

\author{
AAA L Paramasatiari ${ }^{1 *}$, L A P Lestari ${ }^{1}$ \\ ${ }^{1}$ Faculty of Medicine and Health Sciences, Warmadewa Universitas, Jl. Terompong No 24, Denpasar \\ 80235, Indonesia \\ *1ilaparama84@gmail.com
}

\begin{abstract}
Concentration can also be influenced by a person sleep duration. This can affect academic achievement at school. This research aims to find out the correlation between sleep duration, and concentration level in Elementary School students in Denpasar. The research design was cross-sectional study; data were collected using questionnare at three elementary school in Denpasar. The amount of the subjects were 96 respondents was selected by multistage cluster random sampling method from Harapan Mulia, SDN19 Pemecutan, SDN 27 Pemecutan elementary school. Data was analyzed using Chi-Square statistical test by Statistical Package for the Social Sciences for Windows 22 (SPSS) program. The results showed 96 respondents collected from elementary school; $49 \%$ were males and $51 \%$ were females. The most aged of student were 10 years old. The low, medium and high concentration level were 27,1\%; $46,9 \% ; 26 \%$ respectively. The less and enough sleep duration were $67,7 \% ; 32,3 \%$ respectively. The percentage of non-breakfast subject was 35 persons $(36,5 \%)$ and the breakfast subject was 61 persons $(63,5 \%)$. The result was showed that there was a significant relationship $(\mathrm{p}<0,05)$ between sleep duration, with the level of concentration. The conclusion can be drawn that there was a positive and significant relationship between sleep duration and concentration level on Elementary School students.

Keyword : Correlation, Concentration, Elementary School.
\end{abstract}

\section{Introduction}

Conceptually concentration is a focusing of mind or attention on something. Concentration plays a crucial role for children to remember, record, continue, and develop learning material obtained at school. Several factors can influence the concentration of children, such as the environment, relationships, and psychology, including the duration of sleep [1].

A certain condition in the learning process can result in students lacking concentration because of the trigger factors due to students experiencing fatigue and tension before or during the learning process takes place. One of the factors that leads students to experience fatigue is the duration of sleep that is not enough. Sleep defined as an unconscious condition that can be awakened by giving sensory stimuli or by other stimuli. $[2,3,4]$ The time to sleep is night, while the time for not sleeping is daytime. At night, humans tend not to have excessive activity and also the quiet conditions are the reasons that make the night the right time to rest. Sleep habits experience major changes from childhood to adolescence and young adulthood $[1,2,5]$. 
Sleep duration for children under five to the elderly varies. This difference can occur due to several factors, such as illness, environment, fatigue, lifestyle, habits, and sleep disorders. The lack of sleep causes decreased metabolism and bodily functions, especially the brain, so that human health and potential during the day drops significantly or even breaks down. As a result, many education and training are in vain, imperfect performance, declining productivity, loss of income, occurrence of accidents, occurrence of disease, decreased quality of life, and even loss of life. Lack of sleep has an effect on concentration related to academic achievement $[7,8]$.

Data obtained from the Education Office, Denpasar, showed that concentration entered the top three rankings in academic achievement. In Indonesia, studies on the relationship of sleep and its problems, especially among students, which have been carried out to date, are still very few. In the results of studies in the United States and Europe, it was revealed that students were the group of most vulnerable to suffer from lack of sleep. $[9,10]$ As a result, they have a higher risk of experiencing negative impacts, one of which is a negative impact on concentration related to academic achievement. Based on these facts, the current study examines the relationship between sleep duration and concentration level in elementary school students in Denpasar [11,12].

\section{Method}

\subsection{Site of the study}

This study was conducted in October-December 2017 at four elementary schools in Denpasar,Bali, Indonesia.

\subsection{Design and Subject of the Study}

The research design used in this study is descriptive which was conducted with a crosssectional approach. Research data were collected at one time in four elementary schools (SD) in Denpasar, namely SD Harapan Mulia Denpasar, SD Pelita Bangsa Denpasar, SD Negeri 19 Pemecutan, and SD Negeri 27 Pemecutan, with 96 samples that were then classified by age, 912 years.

\subsection{Variables and Data Collection}

There are two variables in this study, namely independent variable and dependent variable. The independent variable is the duration of sleep, while the dependent variable is the level of concentration. The variable of sleep duration is measured using a questionnaire containing a number of questions about the quantity of sleep at night with the category $<10$ hours is lack of sleep and $\geq 10$ hours is enough sleep.

The variable of concentration level is measured using the Grid Concentration Test questionnaire with the criteria of scores good, moderate, and poor. The concentration level is categorized as good if it is in the order of numbers 21 , categorized as moderate if pairs of numbers 11-20 could be found, and categorized as poor if the respondents could find pairs of numbers from 00-10 in a specified time (1 minute).

Data collection was done through questionnaires distributed to the respondents, and the results were also collected on the same day.

\subsection{Data Analysis Technique}


The assessment criteria for the variable of duration of sleep are enough sleep and or lack of sleep and for variable of concentration level are good, moderate, and poor. The data analysis techniques applied in this study are descriptive analysis, Chi-Square statistical test, and Somers'd correlation test with the Statistical Package for the Social Sciences for Windows (SPSS) program.

\section{Results And Discussion}

Of the 96 samples studied, all data can be analysed. Classification results of sample characteristics of the research subjects are presented in table 1.

Table 1. Characteristics of Sample

\begin{tabular}{lc}
\hline \multicolumn{1}{c}{ Characteristics } & Frequency \\
\hline Sex Male & $47(49)$ \\
Female & $49(51)$ \\
Age & \\
9 years & $9(9,4)$ \\
10 years & $50(52,1)$ \\
11 years & $31(32,3)$ \\
12 years & $6(6,3)$ \\
Sleep Duration & $65(67,7)$ \\
Lack & $31(32,3)$ \\
Enough & \\
Concentration Level & $26(27,1)$ \\
Bad & $45(46,9)$ \\
Modeate & $25(26,0)$ \\
Good &
\end{tabular}

Table 1 shows that the ratio between men and women is almost the same and is dominated by the age of 10 years. Based on a total of 96 samples, $67.7 \%$ experienced a case of sleep deprivation, and the dominating concentration level is $46.9 \%$ and is in the moderate category.

The majority of students who have enough sleep have good concentration levels and numbered 25 people $(26.0 \%)$. The students who have enough sleep and have a moderate concentration level are 6 people $(6.3 \%)$. Students who have enough sleep and have a poor level of concentration do not exist. ( Shown in table 2)

There is a positive and significant relationship $(\mathrm{p}<0.05)$ between sleep duration and concentration level with somers' value of 0.884 . (Shown in table 3 )

Grounded by the results of the study, the research respondents who are female are more than 49 people $(51 \%)$ and men are 47 (49\%). The female participants dominate more in this study because the elementary school students, the location of this study, have more female than male. This can be due to the fact that most elementary school students in Denpasar are women and those who fulfill the inclusion criteria are the women themselves. Judging from the characteristics of respondents based on age it is found that the age of respondents is mostly 10 years old $(52.1 \%)$, followed by those aged 11 years $(32.3 \%)$, those aged 9 years $(9.4 \%)$, and the most few are those aged 12 years old (6.3\%). Of the 96 respondents there are 65 
people $(67.7 \%)$ respondents who experience problems of lack duration of sleep. The results of the study imply that lack sleep duration is more dominant than enough sleep one.

This is in line with the results of the study conducted by Masyeni, with the study sample being elementary school students, which revealed that the majority of elementary school students had a lack of quantity of sleep duration, with a number reaching 45 people $(57.7 \%)$ [1]. In this modern era, human activity is increasing so that the attention to the quantity of adequate sleep duration is still lacking.

Table 2. Cross Tabultion

\begin{tabular}{llllll}
\hline & & \multicolumn{3}{c}{ Concentration Level } & \multirow{2}{*}{ Total } \\
\cline { 3 - 5 } & & \multicolumn{1}{c}{ Poor } & \multicolumn{1}{c}{ Moderate } & \multicolumn{1}{c}{ Good } & \\
\hline Durati & Lack & $26(27,1 \%)$ & $39(40,6 \%)$ & $0(0 \%)$ & $65(67,7 \%)$ \\
on of & Enough & $0(0 \%)$ & $6(6,3 \%)$ & $25(26,0 \%)$ & $31(32,3 \%)$ \\
sleep & Total & $26(27,1 \%)$ & $45(46,9 \%)$ & $25(26,0 \%)$ & $96(100 \%)$ \\
\hline
\end{tabular}

National Sleep Foundation index survey shows that as many as $45 \%$ of US students suffer from lack of sleep. In addition, the 2003 American International Assurance (AIA) healthy lifestyle index survey conducted by a global research company, Taylor Nelson Sofrens (TNS), showed that Indonesian students have less sleep duration, can only be realized for 6.8 hours each days because of the increasing quantity of activity. [2,3]

Table 3. Analysis Test Result

\begin{tabular}{|c|c|c|c|c|c|c|c|}
\hline & & \multicolumn{3}{|c|}{ Concentration Level } & \multirow{2}{*}{ Total } & \multirow{2}{*}{$x 2$} & \multirow{2}{*}{$\mathbf{P}$} \\
\hline & & Poor & Moderate & Good & & & \\
\hline Duration & Lack & 26 & 39 & 0 & 65 & 72,217 &, 000 \\
\hline of Sleep & Enough & 0 & 6 & 25 & 31 & & \\
\hline & & \multicolumn{3}{|c|}{ Value } & \multicolumn{3}{|c|}{$\mathrm{P}$} \\
\hline \multicolumn{3}{|c|}{ Concentration of dependent } & 884 & & &, 000 & \\
\hline
\end{tabular}

According to the results of the analysis on the data from the questionnaire, the majority of respondents often sleep late because they spare a lot of time in playing with their gadgets and often wake up at night because of nightmares. The study conducted by Widodo and Soetomenggolo proved that $25 \%$ of children aged 6-12 years still experience nightmares. Nightmares can be caused by various factors, but some of them are avoidable, for example by giving special food at night, such as chocolate, cheese, and coca-cola; television programs, during the incubation period of illness, worry about something will often occur [4]. Factors of electronic devices greatly impact the quantity of one's sleep, such as internet access and equipment in the bedroom such as television, gadgets, and computers [5].Based on the results of study conducted by Garrison et al. entitled " Media Use and Child Sleep: The Impact of Content, Timing, and Environment ", the use of gadgets, including the internet, increases the stimulus in children so that they are always active, besides that it also causes delay in heir time sleeping, and the further impact that occurs is an increase in the frequency of waking up at night and nightmares in children often takes place [6]. This late sleep affects the sleep duration that is getting less in children which causes headaches, increased fatigue, impaired perception, and disorientation of place and time [7]. Additionally environmental factors can also affect sleep duration. This is in line with Ermayani's research which found that there is a relation between post-earthquake environmental conditions and the fulfilment of sleep duration in 
elementary school-aged children. This previous research revealed that good environmental conditions determine the need for sleep to be better, and vice versa, if the environmental conditions are not good, meeting the need for sleep will also be less [8]. The quantity of sleep that is less able to affect mood, alertness, energy, and concentration. The sleep process produces extraordinary power. Sleep restores, rejuvenates, and energizes the body and the brain. [9]

The results of the study show that the concentration level of the highest number of respondents is with the medium category $(46.9 \%)$. This is in line with the research conducted by Nuramaliana which found that the elementary school students who have moderate levels of concentration are dominated by students with 45 students (42\%) [10]. One of the factors that influence the level of concentration is age. According to Arifin and Prihanto, the age also influences the ability to concentrate for individuals because the ability to concentrate is also developing according to the age. The capacity to concentrate in children is more limited compared to that in adults, so the concentration is easily unfocused [11]. The level of concentration is also influence by factors of knowledge and experience. In Muchtar's research, individuals will focus their attention on objects whose patterns have not been able to identified, so that their experience and knowledge can facilitate the concentration [12]. Other factor that influences the level of concentration is physical factor, namely the condition of fatigue or a state of illness that will affect the ability of the central nervous system. Muchtar's study reveals that the condition of the nervous system affects the ability of individuals to select a number of information in attention activities [12]. Individuals have different brain nerve abilities in selecting a number of information available that also influence their ability to focus the attention. Health will affect concentration, but it is also triggered by fatigue, lack of enthusiasm, ease of dizziness, drowsiness, lack of blood, stressors, or a disorder in the function of the senses and the body [13]. The results of the study data analysis found that there were no $(0 \%)$ boxes whose expected value was $<5$. The smallest expected value was 8.07. Chi-Square test requirements were met. The Chi-Square test conditions are no cell with a reality or Actual Count (F0) value of zero (0) and a table of more than $2 \times 2$, so the number of cells with an expected frequency that is less than 5 cannot be more than 20 percent [14]. The Chi-Square value of the table with df is found to be 2 and the probability value of 5 percent or 0.05 is found to be at 5.991. As the value of Pearson Chi-Square is 72,217> Chi-Square table $=5,991$ and significance value or p-value is $0,000<0,05$, Ho is rejected and Ha is roasting that there is a relationship between sleep duration and concentration level in elementary school students in Denpasar. Somers'd's analysis shows the value of the dependent variable, which is the concentration level is 0.884 , which means that sleep duration and concentration levels have a strong relationship and any increase in sleep duration will be associated with increased concentration in elementary school students in Denpasar. In cross tabulation about sleep duration and concentration level, it was found that students who had adequate sleep and good concentration were 25 people $(26.0 \%)$ but the results of this study found that no students had adequate sleep and poor concentration. The same thing also happened in the results of Eliasson \& Lettieri's study which found that students who lack sleep (have a lack of sleep quantity) will tend to feel sleepy during the day, feel tired, and affect the atmosphere (mood) so that eventually will make the concentration go down [15]. This also complies with the results of the study conducted by Masyeni which shows that there is a relationship between the quantity of sleep and concentration in elementary school students [1]. Someone who has sufficient quantity of sleep will have an effect on good sleep quality and thus will have good concentration. This is in line with the sleep function that good quality sleep will maintain mental, emotional, good concentration, and reduce stress in the lungs. Energy is stored during 
sleep, so that it can be redirected to important cellular functions. In general there are two physiological effects of sleep: the first is the effect on the nervous system which is expected to restore normal sensitivity and balance between various nervous structures, and second is the effect on the body's structure by restoring freshness and function in body organs due to sleep, decrease in this function happens. Sleep brings back body activity and balance to normal levels. In a healthy adult a normal heart rate ranges from 70-80 times per minute and when going to sleep it drops to around 60 times per minute or even lower. This shows that in working sleep conditions the heart is lighter 10-20 times less per minute, during sleep conditions, the skeletal muscle will relax progressively so that it will save more energy for important cellular processes [16].

Students with less quantity of sleep will have a poor state of activity during the day, fatigue, emotionally sensitive feelings, poor concentration, and decreased ability to move [17]. This result is supported by the results of previous studies conducted by Putri, which found that poor sleep quality affects the concentration so that it will adversely affect learning achievement [18]. In addition, this result is also in line with the result of Indrawati's study, which shows that there are differences in concentration resulted from the poor quantity of sleep. The lack of sleep duration causes hemoglobin levels to be low, causing disruption in the learning process due to the lack of concentration [19]. The results of study conducted by neurologist Bryce Mander and Matthew Walker from the University of Berkeley proved that if a person has sufficient quantity of sleep, it would help change their short-term memory in the hippocampus into long-term memory stored in the prefrontal cortex. This will cause the memory to be better and longer [20]. A study conducted by Puspito found that if sleep disruption increases, concentration also decreases and affects the learning achievement [21]. Obstacles to learning achievement that are more commonly experienced are caused by drowsiness and fatigue in attending the lessons as a result of lack of sleep [22]. According to the results of Modjod's study, a lack quantity of sleep is likely to affect the ability of the nervous system, and the condition of the nervous system will affect one's individual's ability to select a number of information in attention activities, so that this affects an individual's ability to focus the on something (concentration) [23]. sleep duration potentially has a great impact on human health. It influences many processes and mechanisms in the body, which can lead to adverse health outcomes in both the short and the long term.[24] The sleep of students is often variable in both duration and timing, with many students suffering from considerable sleep deficiency. Short sleep duration has been associated with cognitive impairments, including increased reaction time and reduced cognitive.[25] Studies assessing the impact of sleep on academicperformance focus primarily on teens, adolescents, and un-dergraduate students. Few studies have explored sleephabits in populations of students who are pursing healthcare degrees. Those studies found sleep duration were correlated with changes in academic performance. It related with concentration of student when follow their lesson. [26]

\section{Conclusions}

There is a relationship between sleep duration and concentration level. Sleep duration affects the level of concentration in students in four primary schools in Denpasar. Many studies claim that the lack of sleep at night triggers the brain to be forced to work hard and suffer from fatigue. Fatigue in the brain can cause a person's memory loss. This condition causes a person to experience difficulties in analyzing and absorbing information, so it makes 
them tend to forget easily. The lack of sleep duration needs will have an impact on the ability to concentrate, make decisions, and participate in daily activities.

\section{References}

[1] Masyeni, Catur. 2010. Hubungan Kualitas Tidur dengan Konsentrasi Belajar Siswa SD Muhammadiyah Wirobrajan 3 Yogyakarta Tahun 2010. Skripsi. Yogyakarta: Sekolah Tinggi Ilmu Kesehatan 'Aisyiyah

[2] Hitti M. 2008. WebMD Health News: U.S. Teens Falling Short on Sleep, Available at: http://www.medscape.com/viewarticle/ 528662 (Accessed on: 20 November 2017)

[3] Taylor Nelson Sofrens (TNS). 2013. Survei indeks pola hidup sehat American International Assurance (AIA). Indonesia.

[4] Widodo, Dwi P., Soetomenggolo, Taslim S. 2000. Perkembangan Normal Tidur pada Anak dan Kelainannya. Sari Pediatri, Vol. 2, No. 3

[5] Syamsoedin, W. K. 2015. Hubungan Durasi Penggunaan Media Sosial Dengan Kejadian Insomnia Pada Remaja Di SMA Negeri 9 Manado.

[6] Garrison, MM., Liekweg, K., Christakis, D.A., 2011. Media Use and Child Sleep: The Impact of Content, Timing, and Environment. Dalam: Pediatrics, Official Journal of the American Academy of Pediatrics. 2011; 128(1):29-35

[7] Kozier, B., et al. 2004. Fundamental of nursing: concepts, process, and practice 7th ed. New Jersey: Prentice-Hall, Inc.

[8] Ermayani, Made. 2008. Hubungan Lingkungan Pasca Gempa dengan Pemenuhan Kebutuhan Istirahat Tidur Anak Usia Sekolah. Jurnal Ilmu Keperawatan UGM

[9] Maas, J. B. (2002). Power Sleep: Kiat-Kiat Sehat untuk Mencapai Kondisi dan Prestasi Puncak. Bandung: Kaifa.

[10] Nuramaliana, Siti. 2016. Konsentrasi Belajar dan Penyesuaian Diri pada Siswa Kelas VII di SMPN 1 Ciawigebang Tahun Ajaran 2016/2017. Skripsi. Yogyakarta: Universitas Negeri Yogyakarta.

[11] Arifin, L. A. \& Prihanto, J. B. 2015. Hubungan Sarapan Pagi Dengan Konsentrasi Siswa Di Sekolah. Jurnal Pendidikan Olahraga Dan Kesehatan, 3.

[12] Muchtar, M. 2009. Hubungan antara Sarapan dan Jajan dengan Kemampuan Konsentrasi pada Remaja SMA di Kota Palangkaraya.PSIK FK UGM.

[13] Slameto. 2013. Belajar dan Faktor Belajar yang Mempengaruhinya. Jakarta: Rineka Cipta.

[14] Hartono. 2012. Statistik Untuk Penelitian. Yogyakarta: Pustaka Belajar

[15] Eliasson AH, Lettieri CJ. 2010. Early to bed, early to rise! sleep habits and academic performance in college students. Sleep Breath.14(1):71-5.

[16] Potter, P.A., \& Perry, A.G. 2009. Fundamental Keperawatan, edisi 7. Buku ke 1. Jakarta: Salemba Mediaka

[17] Berman \& Kozier. 2008. Fundamental of Nursing. United States of America: Pearson Education Inc.

[18] Putri, A. A. 2012. Hubungan antara Kualitas Tidur dengan Konsentrasi Belajar dan Indeks Prestasi Mahasiswa Program DIII Kebidanan STIKES 'Aisyiyah Yogyakarta. Available from: http://www.stikes-aisyiyah-jogja. ac.id (Accessed on: 18 September 2017).

[19] Indrawati, Veni. 2004. Pengaruh Anemia Terhadap Konsentrasi Belajar Anak Sekolah Dasar. Jurnal Pendidikan Dasar, Vol. 5: FT UNY.

[20] Mander, Bryce A., Walker, Matthew P., 2017. Sleep and Human Aging. Cell Press Journal 94(1);19-36. 
[21] Puspito. 2009. Hubungan antara Stres denganKejadianInsomniapada Mahasiswa Program Studi Ilmu Keperawatan Universitas Dioponegoro. Available at: http://eprints. undip.ac.id (Accessed on: 5 Desember 2017).

[22] Naja, A.H. 2006. Pendidikan Berkualitas dan Pembangunan SDM. Jakarta: Universitas Indonesia.

[23] Modjod. 2007. Insomnia Experience Management Strategies, and Outcome In ESRD Patient Undergoing Hemodialisis. Tesis. Available at: http://mu/inet8.li.mahidol.ac.th (Accessed on: 20 November 2017).

[24]Luca van Deursen The effects of sleep duration on health: a systematic review of systematic reviews and meta-analyses. Available at https://www.volksgezondheidenzor (2017)

[25] Andrew J. K. Phillips, William M. Clerx, Conor S. O’Brien, Akane Sano, Laura K. Barger, Rosalind W. Picard, Steven W. Lockley, Elizabeth B. Klerman \& Charles A. Czeisler. Irregular sleep/wake patterns are associated with poorer academic performance and delayed circadian and sleep/wake timing Scientific Reportsvolume 7, Article number: 3216. Available at www. Nature.com (2017)

[26]Zeek ML, Savoie MJ, Song M, Kennemur LM, Qian J, Jungnickel PW, Westrick SC1Sleep Duration and Academic Performance Among Student Pharmacists. Am J Pharm Educ. Vol 79(5):63. Available at www.ncbi.nlm.nih.gov (2015) 